KS. JERZY ADAMCZYK* - RADOM

\title{
URZĄD DYREKTORA MUZEUM DIECEZJALNEGO W ASPEKCIE KANONICZNYM
}

W wydanych przez Konferencję Episkopatu Włoch w grudniu 1992 r. „Wytycznych dotyczących kościelnych dóbr kultury we Włoszech" (I beni culturali della Chiesa in Italia. Orientamenti), czytamy:

Gdy konserwacja dzieł sztuki w ich miejscach macierzystych nie jest możliwa, ponieważ przestały już one spełniać funkcje kultyczne lub przedsięwzięcie to jest bardzo ryzykowne, należy ustanowić muzea diecezjalne lub międzydiecezjalne, bądź też przynajmniej uporządkowane kolekcje i wystawy. Liczebny przyrost i ustanawianie nowych muzeów diecezjalnych znacznie przyczynia się do zaznajamiania z diecezjalnym dziedzictwem artystycznym, do ożywiania i wspierania zaangażowania instytucji kościelnych (w ramach ich kompetencji) na rzecz ochrony i dowartościowywania dziedzictwa kulturowego. W obrębie każdej diecezji muzeum diecezjalne stanowi naturalny punkt odniesienia dla analogicznych instytucji kościelnych pod względem organizacyjnym i techniczno-naukowym oraz dla inicjatyw kulturalnych i duszpasterskich ${ }^{1}$.

Przytoczony tekst podaje w sposób klarowny istotne powody, które skłaniają do tworzenia w każdej diecezji muzeum diecezjalnego, jak również nakreśla zadania, które ma ono spełniać w Kościele partykularnym. Zasadniczo są dwa takie zadania: konserwacja diecezjalnego dziedzictwa artystycznego oraz jego dowartościowanie także na płaszczyźnie ściśle duszpasterskiej. U źródeł każdego muzeum diecezjalnego znajdują się praktyczne motywy ochrony, konserwacji i dowartościowania dziedzictwa artystycznego i kulturowego, będącego własnością Kościoła ${ }^{2}$.

* Ks. Jerzy Adamczyk - dr hab. prawa kanonicznego; profesor Wyższego Seminarium Duchownego w Radomiu; e-mail: ksjerzyad@wp.pl

${ }^{1}$ Conferenza Episcopale Italiana, I beni culturali della Chiesa in Italia. Orientamenti (9 dicembre 1992), nr 20, „Notiziario della Conferenza Episcopale Italiana”, (1992) s. 309-336; por. G. Menis, Muzea Kościoła, „Communio”, wersja polska 16 (1996) z. 6, s. 89.

${ }^{2}$ Por. Menis, Muzea Kościoła, s. 89. Kan. 1220 §2 KPK postanawia: „Dla ochrony dóbr sakralnych oraz kosztowności należy okazać właściwą troskę o konserwację i zastosować odpowied- 
Będąc instytucją zajmującą się materialnymi dobrami kulturowymi, muzeum diecezjalne nie różni się od zwykłych muzeów (świeckich). Jego specyfika jednak wypływa z faktu, że otacza ono troską szczególny rodzaj dóbr kulturowych, tj. religijny. Muzeum diecezjalne, zajmując się wyłącznie religijnymi dobrami kulturowymi, przywraca właściwą im wartość, akcentując przede wszystkim ich rolę konkretnego świadectwa dawnej religijności wierzących ${ }^{3}$.

Muzeum diecezjalne choć ma swoja specyfikę, to jednak, jak każda instytucja tego typu, potrzebuje określonego i wykwalifikowanego personelu. Wśród pracowników wspomnianego muzeum naczelne miejsce zajmuje jego dyrektor. To właśnie urząd dyrektora muzeum diecezjalnego będzie przedmiotem niniejszego artykułu.

\section{Potrzeba urzędu dyrektora muzeum diecezjalnego}

Według Stownika wyrazów obcych muzeum to „instytucja gromadząca, przechowująca i konserwująca zbiory z różnych dziedzin kultury, sztuki, nauki i techniki i udostępniająca je publiczności w formie wystaw stałych, czasowych lub objazdowych”, jak również „lokal, budynek mieszczący taką instytucję i zbiory”4. $\mathrm{Z}$ kolei Mały słownik terminów plastycznych określa muzeum, jako ,instytucję mającą na celu zbieranie, ochronę przed zniszczeniem i odpowiednie eksponowanie przedmiotów z różnych dziedzin m.in. sztuki" 5 .

Muzeum kościelne ma wielorakie zadania, które sprowadzają się do ochrony, konserwacji, dowartościowania oraz udostępniania dziedzictwa artystycznego i kulturowego, będącego własnością Kościoła ${ }^{6}$. W kan. $1220 \S 2$ ustawodawca kodeksowy postanawia: „dla ochrony dóbr sakralnych oraz kosztowności należy okazać właściwą troskę o konserwację i zastosować odpowiednie środki bezpieczeństwa".

W muzeum kościelnym zbiera się rękodzieła o różnej naturze i jakości estetycznej, pochodzące z kościołów i innych miejsc, w których - z różnych przyczyn - nie mogą już one spełniać swej pierwotnej funkcji kulturalnej lub liturgicznej i nie da się ich adekwatnie konserwować i dowartościować. Są to przedmioty, którymi - ze względu na ich ścisły związek z historią kultury - jest zainteresowane społeczeństwo, określając je jako „dobra kultury” czyli dobra, w których „uznaje się wartość cywilizacji”. Nad nimi właśnie muzeum kościelne rozciąga swą opie-

nie środki bezpieczeństwa”. „Przy Kongregacji ds. Duchowieństwa istnieje Papieska Komisja dla Strzeżenia Dziedzictwa Artystyczno-Historycznego, której zadaniem jest przewodniczenie trosce o dziedzictwo historyczno-artystyczne całego Kościoła. Do tego dziedzictwa należą na pierwszym miejscu wszystkie dzieła sztuki z przeszłości, które trzeba strzec i konserwować. Te zaś, które przestały służyć własnemu celowi, powinny być umieszczone w muzeach lub innych miejscach, aby mogły być oglądane. Ioannes Paulus P.P. II, Constitutio Apostolica Pastor Bonus (dalej: PB), (28 iulii 1988), art. 99-100, „Acta Apostolicae Sedis”, 80 (1988) s. 841-912.

${ }^{3}$ Por. Menis, Muzea Kościoła, s. 90.

${ }^{4}$ Stownik wyrazów obcych. Wydanie nowe, red. E. Sobol, Warszawa 1991, s. 752.

${ }^{5}$ Mały stownik terminów plastycznych, red. K. Zwolińska, Z. Malicki, Warszawa 1990, s. 192.

${ }^{6}$ Por. Menis, Muzea Kościoła, s. 89. 
kę, patronując ich zbieraniu, restaurowaniu, ochronie, konserwacji, naukowemu opracowywaniu i dowartościowaniu?

Muzeum diecezjalne może funkcjonować dzięki odpowiedniej kadrze pracowników. Dodatkowo muszą być to osoby o określonych kwalifikacjach przydatnych do pracy w tej instytucji. Wielość zadań omawianego muzeum wymaga nie tylko zatrudnienia pracowników, ale i określonej organizacji. Aby było to możliwe, na czele omawianej placówki musi być osoba kierująca, czyli dyrektor muzeum diecezjalnego.

Muzeum kościelne jest instytucją utworzoną w celu gromadzenia, zabezpieczenia przed zniszczeniem i zapewnienia fachowej konserwacji oraz prezentacji obiektów sakralnych (nieużywanych w kulcie), dla realizacji celów Kościoła, będąca w posiadaniu instytucji aprobowanych albo erygowanych kanonicznie. Muzeum diecezjalne, jak każde muzeum kościelne, jest więc instytucją opartą na prawie kościelnym i włączoną w porządek kanoniczny, stąd także stanowisko dyrektora muzeum jest urzędem w rozumieniu kan. 145 §1, w myśl którego „urząd kościelny jest jakimkolwiek ustanowionym na stałe zadaniem z postanowienia czy to Bożego, czy kościelnego dla realizacji celu duchowego", a „obowiązki i prawa właściwe każdemu urzędowi kościelnemu są określane albo samym prawem, którym urząd ustanowiono, albo dekretem kompetentnej władzy, którym jest on równocześnie ustanowiony i nadany" dawcy kościelni normują zadanie dyrektora muzeum diecezjalnego wydając $\mathrm{w}$ tej kwestii odpowiednie normy prawne.

Prawodawcy wskazują na pierwszym miejscu potrzebę istnienia urzędu dyrektora muzeum diecezjalnego. Konferencja Episkopatu Polski w Statucie Muzeum Diecezjalnego postanawia: ,na czele Muzeum Diecezjalnego stoi dyrektor, którego mianuje Ordynariusz miejscowy", a Statuto del Museo Diocesano di Arte Sacra Diocesi di San Benedetto del Tronto, Montalto, Ripatransone przypomina, że kierownictwo i odpowiedzialność za funkcjonowanie muzeum powierzane jest dyrektorowi mianowanemu przez biskupa diecezjalnego ${ }^{10}$. Podobnie na temat dyrektora wypowiada się Statut Muzeum Diecezjalnego w Trydencie, gdzie

\footnotetext{
${ }^{7}$ Por. tamże, s. 89-90.

${ }^{8}$ Kan. $145 \S 2$.

${ }^{9}$ Statut Muzeum Diecezjalnego uchwalony przez Konferencję Episkopatu Polski dnia (18 listopada 1976) (dalej: Statut Muzeum Diecezjalnego uchwalony przez Konferencję Episkopatu Polski) nr 14, „Currenda” 127 (1977) nr 5-8, s. 169-170. „Na czele Muzeum stoi dyrektor. Dyrektora Muzeum powołuje Biskup Łomżyński”. Statut Muzeum Diecezjalnego w Łomży (dalej: Statut Muzeum Diecezjalnego w Łomży) §8, www.kuria.lomza.pl (dostęp: 21.09.2015). „Archiwum i Muzeum Archidiecezjalnym w Białymstoku kieruje dyrektor, którego powołuje i odwołuje Arcybiskup Metropolita Białostocki”. Arcybiskup Metropolita Białostocki, Statut Archiwum i Muzeum Archidiecezjalnego w Bialymstoku (4 maja 2012) (dalej: Statut Archiwum i Muzeum Archidiecezjalnego w Białymstoku), ,Wiadomości Kościelne Archidiecezji Białostockiej” 40 (2012) nr 2, s. 69-74, §11, nr 1, s. 72. „Na czele Muzeum stoi dyrektor, którego powołuje i odwołuje Biskup Kaliski”. Statut Muzeum Diecezji Kaliskiej (3 lutego 2011) (dalej: Statut Muzeum Diecezji Kaliskiej). nr 16, „Diecezja Kaliska. Pismo Kurii Diecezjalnej” 19 (2011) nr 1, s. 108.

${ }^{10}$ Statuto del Museo Diocesano di Arte Sacra Diocesi di San Benedetto del Tronto, Montalto, Ripatransone, sistemimuseali.sns.it (dostęp: 23.08.2015), art. 5.
} 
czytamy, że dyrektor jest nominowany przez biskupa i reprezentuje we wszystkich sprawach Trydenckie Muzeum Diecezjalne, także w stosunkach z władzą cywilną ${ }^{11}$. Natomiast Statut Muzeum Diecezjalnego w Drohiczynie postanawia: „dyrektor Muzeum sprawuje bezpośredni zarząd wewnętrzny i zewnętrzny, administracyjny i naukowy, reprezentuje muzeum na zewnątrz" ${ }^{2}$, a Statut Archiwum i Muzeum Archidiecezjalnego w Białymstoku zawiera następująca normę: „,dyrektor Archiwum i Muzeum Archidiecezjalnego kieruje całokształtem działalności Archiwum i Muzeum oraz czuwa nad prawidłową realizacją zadań statutowych"13.

Pierwszy Synod Diecezji Zamojsko-Lubaczowskiej mówiąc o potrzebie urzędu dyrektora postanawia: „Na czele Muzeum stoi dyrektor, mianowany przez Biskupa Diecezjalnego" ${ }^{14}$, jak również: „dyrektor reprezentuje Muzeum na zewnątrz i odpowiada za całość prac przed Biskupem Diecezjalnym"15, podobnie wypowiada się Synod Archidiecezji Wrocławskiej: ,na czele Muzeum stoi dyrektor mianowany przez ordynariusza archidiecezji, który sprawuje bezpośredni zarząd zewnętrzny i wewnętrzny nad instytucją"16. Także Synod Pelpliński przypomina, że „całością prac Muzeum kieruje dyrektor mianowany przez biskupa diecezjalnego" $"$.

O konieczności stanowiska dyrektora muzeum diecezjalnego prawodawcy mówią, w następującym postanowieniu: „Muzeum Diecezjalne może tworzyć filie rejonowe, które będą podlegały dyrektorowi Muzeum Diecezjalnego"18. Także normy traktujące o Radzie Muzealnej działającej przy muzeum diecezjalnym będącej organem doradczym i opiniodawczym, której członków powołuje Biskup Diecezjalny na wniosek dyrektora Muzeum, świadczą o nieodzowności urzędu dyrektora muzeum ${ }^{19}$. Na potrzebę urzędu omawianego dyrektora wskazuje następująca norma prawna: ,[dyrektor muzeum] może mieć zastępcę, jeśli potrzeby Muzeum tego wymagają i Ordynariusz diecezji uzna to za stosowne"20.

${ }^{11}$ Statuto del Museo Diocesano Tridentino (21 settembre 1981), (dostęp: 23.08.2015), nr 4b.

${ }^{12}$ Biskup Drohiczyński, Statut Muzeum Diecezjalnego w Drohiczynie (3 marca 2005), nr 44, „Komunikaty Kurii Diecezjalnej w Drohiczynie n. Bugiem” 18 (2005), nr 2, s. 46.

${ }^{13}$ Statut Archiwum i Muzeum Archidiecezjalnego w Bialymstoku, §12, nr 1, s. 73.

${ }^{14}$ Statut muzeum diecezjalnego, w: Pierwszy Synod Diecezji Zamojsko-Lubaczowskiej 19962001, Zamość 2001, §9, s. 206, (odtąd: Pierwszy Synod Diecezji Zamojsko-Lubaczowskiej, Statut muzeum diecezjalnego).

15 Tamże, § 10, s. 206.

${ }^{16}$ Synod Archidiecezji Wrocławskiej 1985-1991 (dalej: Synod Wrocławski), Wrocław 1995, nr 3, s. 365 .

${ }^{17}$ Statuty I Synodu Diecezji Pelplińskiej, Pelplin 2001, Statut Muzeum Diecezjalnego w Pelplinie, (dalej: Statut Muzeum Diecezjalnego w Pelplinie). §14, s. 158.

${ }^{18}$ Statut Muzeum Diecezjalnego uchwalony przez Konferencje Episkopatu Polski, nr 24; por. Pierwszy Synod Diecezji Zamojsko-Lubaczowskiej, Statut muzeum diecezjalnego, §16, s. 207.

${ }_{19}$ Pierwszy Synod Diecezji Zamojsko-Lubaczowskiej, Statut muzeum diecezjalnego, §13, 1, s. 207; Statut Muzeum Diecezjalnego uchwalony przez Konferencję Episkopatu Polski, nr 19-20.

${ }^{20}$ Statut Muzeum Diecezjalnego uchwalony przez Konferencję Episkopatu Polski, nr 18. 
Pośrednio o istnieniu urzędu dyrektora muzeum diecezjalnego mówi dokument Konferencji Episkopatu Włoch I beni culturali della Chiesa in Italia. Orientamenti o personelu zarządzającym muzeów kościelnych ${ }^{21}$.

Jak wszystkie urzędy w diecezji także urząd dyrektora muzeum diecezjalnego podlega biskupowi diecezjalnemu i ten konsekwentnie swobodnie mianuje wymienionego dyrektora. O tym uprawnieniu i obowiązku biskupa traktują dokumenty kanoniczne. I tak np. „w tworzeniu muzeum, tam gdzie to możliwe, jest właściwym utworzyć specjalny Komitet, złożony z ekspertów i kierowany przez dyrektora mianowanego przez biskupa" 22 , „, na czele Muzeum stoi dyrektor mianowany przez ordynariusza archidiecezji” ${ }^{23}$, „całością prac Muzeum kieruje dyrektor mianowany przez biskupa diecezjalnego" ${ }^{24}$, „na czele Muzeum Diecezjalnego stoi dyrektor, którego mianuje Ordynariusz miejscowy”25, czy „kierownictwo i odpowiedzialność za funkcjonowanie Muzeum powierza się Dyrektorowi mianowanemu przez Biskupa diecezjalnego" 26 .

Gdy idzie o odwołanie (usunięcie) dyrektora muzeum diecezjalnego to dokonuje tego swobodnie biskup diecezjalny, lub ordynariusz, który ma władzę mianowania na ten urząd. Wyraźnie mówi na ten temat mówi następujący passus: „urząd Dyrektora (muzeum diecezjalnego) jest nadawany na czas nieokreślony i rozwiązuje się go poprzez dobrowolną rezygnację albo poprzez odwołanie przez Biskupa ze skutkiem natychmiastowym, nawet bez uzasadnionej przyczyny lub powodu”27, czy „na czele Muzeum stoi dyrektor, którego powołuje i odwołuje Biskup Kaliski" 28 .

Co do możliwości rekursu usuniętego dyrektora muzeum diecezjalnego trzeba zauważyć, że ma on możliwość rekursu administracyjnego do Kongregacji Duchowieństwa ${ }^{29}$. Od decyzji wspomnianej Kongregacji usunięty dyrektor może odwołać się do Sygnatury Apostolskiej z tytułu nielegalności aktu ${ }^{30}$.

${ }^{21}$ Conferenza Episcopale Italiana, I beni culturali della Chiesa in Italia. Orientamenti (9 dicembre 1992), cz. IV, nr 13, „Notiziario della Conferenza Episcopale Italiana” (1992), s. 309-336.

${ }^{22}$ Pontificia Commissione per i Beni Culturali della Chiesa, Lettera circolare La funzione pastorale dei musei ecclesiastici (29 iunii 2001), nr 2. 4, w: Enchiridion dei Beni Culturali della Chiesa. Documenti ufficiali della Pontificia Commissione per i Beni Culturali della Chiesa, Edizioni Dehoniane, Bologna 2002, s. 464-526.

${ }^{23}$ Synod Wroctawski, nr. 3, s. 365.

${ }^{24}$ Statut Muzeum Diecezjalnego w Pelplinie, §14, s. 158.

${ }^{25}$ Statut Muzeum Diecezjalnego uchwalony przez Konferencję Episkopatu Polski, nr 14.

${ }^{26}$ Statuto del Museo Diocesano di Arte Sacra Diocesi di San Benedetto del Tronto, Montalto, Ripatransone, art. 5.

${ }^{27}$ Tamże.

${ }^{28}$ Statut Muzeum Diecezji Kaliskiej, nr 16, s. 108.

${ }^{29}$ Por. kan. 1747 §3; PB, art. 93; por. J. Krukowski, Komentarz do kan. 1747, w: Komentarz do Kodeksu Prawa Kanonicznego. T. V. Ks. VII. Procesy, red. J. Krukowski, Poznań 2007, s. 445.

${ }^{30}$ Benedictus PP. XVI, Litterae Apostolicae motu proprio datae Antiqua ordinatione, ,Quibus Supremi Tribunalis Signaturae Apostolicae lex propria promulgatur," (21 iunii 2008), art. 34 § 1-2, „Acta Apostolicae Sedis”, 100 (2008) s. 513-538; zob. B. Nowakowski, Kompetentne i sprawnie działajace trybunały kościelne. Rzeczywistość czy pobożne życzenie? Możliwości, perspektywy oraz 


\section{Kwalifikacje i formacja dyrektora muzeum diecezjalnego}

Według kan. 149 §1 urząd kościelny można powierzyć komuś, kto pozostaje we wspólnocie Kościoła i jest zdatny, czyli posiada przymioty wymagane do tego urzędu prawem powszechnym, partykularnym lub fundacyjnym. Jest zrozumiałe, że przytoczona norma odnosi się także do urzędu dyrektora muzeum diecezjalnego.

Urząd kościelny można powierzyć jedynie osobie zdatnej, czyli spełniającej wymogi zarówno ogólne, czyli bezwzględne (stawiane kandydatom do jakiegokolwiek urzędu kościelnego), jak też szczegółowe, czyli względne (wynikające z natury urzędu, który ma być nadany). Przymioty wymagane do konkretnego urzędu określa prawo powszechne, partykularne lub fundacyjne - czy to wprost $^{31}$, czy to pośrednio ${ }^{32}$. Sąd o zdatności należy do władzy nadającej urząd, a jeśli jakiś podmiot ma prawo przedstawiania kandydata, winien przedtem upewnić się o jego zdatności. Wymagane przymioty są określane w prawie w sposób albo wiążący ${ }^{33}$, albo też dyrektywny ${ }^{34}$. Ujmuje się je od strony negatywnej ${ }^{35}$ lub pozytywnej ${ }^{36}$.

Tak więc dyrektor muzeum diecezjalnego winien być zdatny, czyli posiadać przymioty wymagane do tego urzędu prawem powszechnym, partykularnym lub fundacyjnym. Kodeks Prawa Kanonicznego z 1983 r. milczy na temat urzędu dyrektora muzeum diecezjalnego i , co jest jasne, zdatności kandydata do tej funkcji.

Odnośnie do kwalifikacji kandydata na to stanowisko wypowiadają się jednak inne dokumenty kościelne. Według Statutu Muzeum Diecezjalnego uchwalonego przez Konferencje Episkopatu Polski „,na czele Muzeum Diecezjalnego stoi dyrektor, którego mianuje Ordynariusz miejscowy. Dyrektor powinien posiadać pełne wykształcenie z zakresu historii sztuki lub konserwacji zabytków, uwieńczone stopniem naukowym" ${ }^{37}$.

Natomiast lettera circolare La funzione pastorale dei musei ecclesiastici przypomina, że dyrektor muzeum diecezjalnego winien odznaczać się odpowiedzialnością, szczególną wiedzą specjalistyczną i zaangażowaniem ${ }^{38}$, a Regolamento del Museo Diocesano Tridentino postanawia, że kwalifikacje kandydata na dyrektora winny odpowiadać wymogom odnośnie przygotowania kulturowego właściwego dla zadań jego urzędu ${ }^{39}$.

Wydaje się, że kandydat na dyrektora muzeum diecezjalnego przez pewną analogię do kwalifikacji proboszcza winien nie tylko wyróżniać się zdrową nauką

konieczność zmian po stowach Benedykta XVI do Sygnatury Apostolskiej w 2011 r., „Prawo Kanoniczne", 54 (2011) nr 3-4, s. 330.

${ }^{31}$ Np. kan. 478; 494 §1.

${ }^{32} \mathrm{~Np}$. jako zdatność do biskupstwa - kan. 378 §1, czy do kapłaństwa - kan. 1026.

${ }^{33}$ Por. np. kan. $378 \S 1$ n. 3 i 4.

${ }^{34}$ Por. np. kan. 378 §1 n. 5: „(...) lub prawdziwej biegłości”.

${ }^{35}$ Np. kan. 317 §4; 483 § 2 - ,ponad wszelkim podejrzeniem”.

${ }^{36}$ Por. R. Sobański, Komentarz do kan. 149, w: Komentarz do Kodeksu Prawa Kanonicznego.

T. 1. Ks. 1. Normy ogólne, red. J. Krukowski, Poznań 2003, s. 239.

${ }^{37} \mathrm{Nr}$ 14; por. Statut Muzeum Diecezjalnego w Lomży, §8; por. Statut Muzeum Diecezji Kaliskiej, nr 16, s. 108.

${ }^{38}$ La funzione pastorale dei musei ecclesiastici, $\mathrm{nr} 14$.

${ }^{39}$ Regolamento del Museo Diocesano Tridentino, cap. V, (dostęp: 23.8.2015). 
i dobrymi obyczajami, lecz również gorliwością apostolską oraz innymi cnotami wymaganymi do należytego wykonywania tego urzędu, a także komunikatywnością oraz uzdolnieniami organizacyjnymi i w dziedzinie zarządzania ${ }^{40}$.

Skoro dyrektor ma tak liczne zadania, to niewątpliwie do godziwego powierzenia mu zadania kierowania muzeum winien posiadać określone przymioty. Oprócz stosownego wykształcenia, zasadniczo w dziedzinie historii sztuki lub konserwacji zabytków uwieńczonego stopniem naukowym, lub prawdziwej biegłości w tej dziedzinie ${ }^{41}$, winien odznaczać się pewnymi przymiotami ludzkimi. W pierwszym rzędzie winien posiadać uzdolnienia organizacyjne i w dziedzinie zarządzania. Ma on bowiem za zadanie np. sprawować bezpośredni zarząd zewnętrzny i wewnętrzny nad muzeum ${ }^{42}$, kierować całością prac muzeum ${ }^{43}$, ponadto kieruje muzeum pod względem techniczno-administracyjnym ${ }^{44}$, podpisuje umowy na prace zlecone, razem $\mathrm{z}$ dyrektorem ekonomicznym diecezji decyduje o wypłatach pieniężnych ${ }^{45}$, prowadzi nadzór nad zbiorami i majątkiem muzeum ${ }^{46}$, kieruje sprawami naukowo badawczymi, organizacyjnymi i administracyjnymi ${ }^{47}$, troszczy się o bezpieczeństwo i integralność muzealiów oraz o odpowiednie ich eksponowanie i udostępnianie zwiedzającym ${ }^{48}$, kieruje Komitetem składającego się z określonych ekspertów przy tworzeniu muzeum ${ }^{49}$, organizuje pomieszczenia dla muzeum, ustala strategię ekspozycji muzealnych ${ }^{50}$, stara się, aby muzeum było licznie odwiedzane ${ }^{51}$.

Inną ważną cechą tego, kto może zostać dyrektorem muzeum diecezjalnego jest komunikatywność i umiejętność współpracy z innymi. Wspomniany dy-

${ }^{40}$ Por. Congregaticio pro Episcopis, Direttorio per il ministero pastorale dei vescovi (22 febbraio 2004), nr 213, Città del Vaticano 2004, tekst polski: Kongregacja do spraw Biskupów, Dyrektorium o pasterskiej posłudze biskupów „Apostolorum Successores” (22 lutego 2004), Kielce 2005; por. kan. 521 §2 w myśl którego aby ktoś mógł zostać proboszczem „ winien (...) odznaczać się zdrową nauką i dobrymi obyczajami, gorliwością pasterską oraz innymi cnotami, jak również przymiotami, wymaganymi, czy to prawem powszechnym czy partykularnym, do kierowania parafią, o którą chodzi”. Podobnie kandydat na dyrektora muzeum diecezjalnego winien posiadać talie przymioty, których wymaga jego urząd.

${ }^{41}$ Wydaje się, że prawdziwa biegłość w dziedzinie historii sztuki lub konserwacji zabytków wystarcza w przypadku muzeów mniejszych, gdzie łatwiej o owocne wykonywanie funkcji dyrektora.

${ }^{42}$ Synod Wrocławski, nr 3, s. 365.

${ }^{43}$ Statut Muzeum Diecezjalnego w Pelplinie, §14, s. 158.

${ }^{44}$ Regolamento del Museo Diocesano Tridentino, cap. V.

${ }^{45}$ Tamże, $\S 15 \mathrm{f}-\mathrm{g}$.

${ }^{46}$ Pierwszy Synod Diecezji Rzeszowskiej, Statut Muzeum Diecezjalnego w Rzeszowie, (dalej: Statut Muzeum Diecezjalnego w Rzeszowie) nr 3 a, Rzeszów 2004, s. 398.

${ }^{47}$ Tamże, nr 3 b, s. 398.

${ }^{48}$ Synod Archidiecezji Przemyskiej 1995-2000. Statuty i aneksy, Statut Muzeum Archidiecezjalnego w Przemyślu, (dalej: Statut Muzeum Archidiecezjalnego w Przemyślu). art. 17, nr 3, Przemyśl 2000, s. 298.

${ }^{49}$ La funzione pastorale dei musei ecclesiastici, $\mathrm{nr} 2,4$.

${ }^{50}$ Tamże.

${ }^{51}$ Tamże. 
rektor kieruje np. całością prac muzeum ${ }^{52}$, razem z dyrektorem ekonomicznym diecezji decyduje o wypłatach pieniężnych ${ }^{53}$, powołuje specjalistów w sprawach szczególnie ważnych dla zabytków i ich konserwacji ${ }^{54}$, wydaje zarządzenia wewnętrzne ${ }^{55}$, stara się o pozyskanie środków finansowych ${ }^{56}$, zatrudnia i zwalnia pracowników muzeum oraz ustala zakres ich obowiązków ${ }^{57}$, ,przyjmuje lub zwalnia - za zgodą Ordynariusza - pracowników muzealnych oraz kieruje ich zajęciami”" ${ }^{3}$, „powołuje specjalistów w sprawach szczególnie ważnych dla zabytków i ich konserwacji” ${ }^{59}$, „powinien utrzymywać kontakty z innymi muzeami kościelnymi i z Ośrodkiem Archiwów, Bibliotek i Muzeów Kościelnych przy Katolickim Uniwersytecie Lubelskim, zwłaszcza w sprawach organizacji zbiorów, metody ich dokumentacji naukowej i opieki nad nimi" ${ }^{60}$, wnioskuje do biskupa diecezjalnego o powołanie członków rady muzeum ${ }^{61}$, osobiście kontroluje i nadzoruje podwładnych ${ }^{62}$, troszczy się o dyscyplinę zwiedzania muzeum i o właściwą konsultację materiałów muzealnych przez uczonych ${ }^{63}$, a także umie współpracować ze swoim zastępcą ${ }^{64}$, czy z odpowiednimi eksperta$\mathrm{mi}^{65}$. Trzeba dodać, że ponieważ urząd dyrektora muzeum diecezjalnego nie wymaga władzy święceń, to jego tytulariuszami mogą być zarówno duchowni, jak i świeccy: kobiety i mężczyźni ${ }^{66}$.

Urząd dyrektora muzeum diecezjalnego wymaga nie tylko posiadania przez jego tytulariusza odpowiednich kwalifikacji. Domaga się również formacji, zarówno przygotowującej do tej funkcji, jak i kształcenia ustawicznego. Dyrektor winien zdobyć przede wszystkim odpowiednią formację naukową i fachową potrzebną ,,do właściwego wykonywania swego zadania, by ją spełniał świadomie, umiejętnie i pilnie" ${ }^{97}$. Winien on zdobyć pełne wykształcenie z zakre-

${ }^{52}$ Statut Muzeum Diecezjalnego w Pelplinie, §14, s. 158.

${ }^{53}$ Tamże, $§ 15$, g.

${ }^{54}$ Statut Muzeum Diecezjalnego w Rzeszowie, $\mathrm{nr} 3$ d, s. 398.

${ }^{55}$ Tamże, nr 3 c, s. 398.

${ }^{56}$ Tamże, nr 3 j, s. 398.

${ }^{57}$ Tamże, nr 4, s. 398.

${ }^{58}$ Statut Muzeum Diecezjalnego uchwalony przez Konferencję Episkopatu Polski, nr 17 b.

${ }^{59}$ Tamże, nr $17 \mathrm{c}$.

${ }^{60}$ Statut Muzeum Archidiecezjalnego w Przemyślu, art. 18, s. 298; por. Statut Muzeum Diecezjalnego uchwalony przez Konferencje Episkopatu Polski, nr 16.

${ }^{61}$ Tamże, art. 24-25, s. 298.

${ }^{62}$ Regolamento del Museo Diocesano Tridentino, cap. V.

${ }^{63}$ Tamże, cap. V.

${ }^{64}$ Por. tamże, cap. V. por. Statut Muzeum Diecezjalnego uchwalony przez Konferencję Episkopatu Polski, nr 18.

${ }^{65}$ La funzione pastorale dei musei ecclesiastici, $\mathrm{nr} 3,4$.

${ }^{66}$ Kan. 228 §1. „Odpowiednio przygotowani świeccy są zdolni, by otrzymać od świętych pasterzy te urzędy kościelne i posługi, które wolno im piastować zgodnie z przepisami prawa”. Oczywiście w przypadku, gdyby prawo partykularne lub statut muzeum wymagał, aby urząd dyrektora muzeum diecezjalnego piastowali wyłącznie duchowni, to świeccy nie mogliby być tytulariuszami tego urzędu.

${ }^{67}$ Kan. $231 \S 1$. 
su historii sztuki lub konserwacji zabytków, uwieńczone stopniem naukowym ${ }^{68}$, posiadać przygotowanie w zakresie kultury ${ }^{69}$, czy posiadać szczególne kompetencje ${ }^{70}$.

Wydaje się, że byłoby rzeczą pożądaną, aby omawiany dyrektor posiadał wiedzę z zakresu prawa państwowego obowiązującego na terytorium, gdzie znajduje się kierowane przez niego muzeum ${ }^{71}$, jak również z dziedziny prawa kanonicznego ${ }^{72}$.

Jest zrozumiałe, że wspomniany dyrektor ma ustawicznie podejmować także formację stałą, np. „powinien utrzymywać kontakty z innymi muzeami kościelnymi i z Ośrodkiem Archiwów, Bibliotek i Muzeów Kościelnych przy Katolickim Uniwersytecie Lubelskim, zwłaszcza w sprawach organizacji zbiorów, metody ich dokumentacji naukowej i opieki nad nimi”73, czy „,powinien utrzymywać kontakty z muzeami kościelnymi innych diecezji i z Ośrodkiem Archiwów, Bibliotek i Muzeów Kościelnych przy Katolickim Uniwersytecie Lubelskim, zwłaszcza w sprawach organizacji zbiorów metody ich dokumentacji naukowej i opieki nad zabytkami na terenie diecezji" "74, lub „dyrektor muzeum utrzymuje kontakty z muzeami, ośrodkami zajmującymi się ochroną zabytków i wydziałami uczelni zajmujących się sztuką, zarówno kościelnymi jak i świeckimi"75.

\section{Zadania dyrektora muzeum diecezjalnego}

Każdy urząd kościelny jest zadaniem ustanowionym na stałe dla realizacji celu duchowego, stąd wynikają z niego określone obowiązki i prawa ${ }^{76}$. Konsekwentnie także stanowisko dyrektora muzeum diecezjalnego niesie za sobą konkretne zadania. Jasno powinny być określone jego funkcje, prawa i obowiązki, które winny być sformalizowane w pierwszym rzędzie w statutach i regulaminach muzeum.

Podstawowym zadaniem dyrektora muzeum diecezjalnego jest kierowanie i reprezentowanie muzeum oraz złączona $\mathrm{z}$ tym odpowiedzialność za jego działalność. Obowiązek ten potwierdzają wyraźnie prawodawcy. I tak „kierownictwo i odpowiedzialność za działalności muzeum są powierzone dyrektorowi

${ }^{68}$ Statut Muzeum Diecezjalnego uchwalony przez Konferencję Episkopatu Polski, nr 14.

${ }^{69}$ Regolamento del Museo Diocesano Tridentino, cap. V.

${ }^{70}$ La funzione pastorale dei musei ecclesiastici, $\mathrm{nr} 3,4$.

${ }^{71}$ Por. Statuto del Museo Diocesano Tridentino, $\mathrm{nr} 4$ b. O konieczności posiadania wiedzy z zakresu prawa państwowego świadczą następujące normy prawne: dyrektor muzeum ,przyjmuje i zwalnia pracowników”. Statut Muzeum Diecezjalnego w Pelplinie, §15 a, s. 158; ,razem z dyrektorem ekonomicznym diecezji (dyrektor) decyduje o wypłatach pieniężnych. Tamże, § $15 \mathrm{~g}$, s. 158.

${ }^{72}$ Por. tamże, nr 4 c. O konieczności posiadania wiedzy kanonistycznej świadczą następujące normy prawne: dyrektor „wydaje zarządzenia wewnętrzne (tyczące się muzeum)”. Statut Muzeum Diecezjalnego w Rzeszowie, nr 3 c, s. 398; ,Muzeum posiada swój statut, zatwierdzony przez biskupa diecezjalnego i ustalony przez dyrektora regulamin wewnętrzny". Statut Muzeum Archidiecezjalnego w Przemyślu, art. 24, s. 300. Statut Muzeum Archidiecezjalnego w Przemyślu, art. 18, s. 298.

${ }^{73}$ Tamże.

${ }^{74}$ Statut Muzeum Diecezjalnego uchwalony przez Konferencję Episkopatu Polski, nr 16.

${ }^{75}$ Statut Muzeum Diecezji Kaliskiej, nr 18, s. 108.

${ }^{76}$ Kan. 145. 
mianowanemu przez biskupa diecezjalnego" "77, „dyrektor reprezentuje Muzeum na zewnątrz i odpowiada za całość prac przed Ordynariuszem diecezji”, ${ }^{7}$, „dyrektor kieruje działalnością [muzeum], reprezentuje je na zewnątrz i odpowiada za nie przed Biskupem Diecezji”79, „dyrektor reprezentuje Muzeum na zewnątrz odpowiada za całość spraw przed Biskupem Łomżyńskim”80, czy „dyrektor reprezentuje Muzeum na zewnątrz i odpowiada za całość prac przed Biskupem Diecezjalnym”"1. Według Statutu Muzeum Diecezjalnego w Drohiczynie „dyrektor muzeum sprawuje bezpośredni zarząd wewnętrzny i zewnętrzny, administracyjny i naukowy" ", natomiast Statut Archiwum i Muzeum Archidiecezjalne w Biatymstoku postanawia, że „dyrektor Archiwum i Muzeum Archidiecezjalnego kieruje całokształtem działalności Archiwum i Muzeum oraz czuwa nad prawidłową realizacją zadań statutowych" ${ }^{83}$.

Istotnym przejawem i zarazem obowiązkiem wynikającym z kierowania i reprezentowania muzeum diecezjalnego jest przedkładanie biskupowi diecezjalnemu, czy ordynariuszowi miejsca, którym podlega, sprawozdań o działalności muzeum. Obowiązek ten wyraźnie akcentują prawodawcy. Np. Statut Muzeum Diecezjalnego uchwalony przez Konferencje Episkopatu Polski zawiera następujący zapis: „dyrektor Muzeum Diecezjalnego składa Ordynariuszowi diecezji coroczne sprawozdanie ze stanu i działalności Muzeum" ", natomiast Statut Muzeum Diecezji Kaliskiej postanawia: ,dyrektor raz w roku przedstawia Biskupowi diecezjalnemu na piśmie sprawozdanie z działalności Muzeum"85, a Statut Muzeum Diecezjalnego $w$ Łomży określa, że „dyrektor [muzeum diecezjalnego] odpowiada za całość spraw przed Biskupem Łomżyńskim"86.

Wyrazem kierowania muzeum diecezjalnym przez jego dyrektora jest przede wszystkim nadanie muzeum właściwej organizacji. W pierwszym rzędzie przy-

${ }^{77}$ Statuto del Museo Diocesano di Arte Sacra Diocesi di San Benedetto del Tronto, Montalto, Ripatransone, art. 5.

${ }^{78}$ Statut Muzeum Diecezjalnego uchwalony przez Konferencję Episkopatu Polski, nr 17.

79 Statut Muzeum Diecezji Kaliskiej, nr 17, s. 108; por. Statut Muzeum Archidiecezjalnego w Przemyślu, art. 17, nr 1, s. 298..

${ }^{80}$ Statut Muzeum Diecezjalnego w Łomży, §10; por. Statut Muzeum Diecezjalnego w Drohiczynie, nr 44, s. 46; por. Statut Archiwum i Muzeum Archidiecezjalnego w Białymstoku, §12, nr 2. 2, s. 73 .

${ }^{81}$ Pierwszy Synod Diecezji Zamojsko-Lubaczowskiej, Statut muzeum diecezjalnego, §10, s. 206.

${ }^{82} \mathrm{Nr}$ 44, s. 46; por. Statut Muzeum Diecezji Kaliskiej, nr 17, s. 108; por. Statut Muzeum Diecezjalnego w Łomży, §10 c; por. Statut Archiwum i Muzeum Archidiecezjalnego w Biatymstoku, §12, nr 2, 1, s. 73.

${ }^{83} \S 12$, nr 1, s. 73.

${ }^{84} \mathrm{Nr} 25$. „Do zakresu działania dyrektora należy w szczególności: (...) przedkładanie Arcybiskupowi Metropolicie Białostockiemu sprawozdań rocznych z działalności Archiwum i Muzeum Archidiecezjalnego". Statut Archiwum i Muzeum Archidiecezjalnego w Białymstoku, §12, nr 2, 5, s. 73.

${ }^{85} \mathrm{Nr} 19$, s. 108.

${ }^{86} \S 10$. „Dyrektor składa Biskupowi Diecezjalnemu coroczne sprawozdania z całokształtu działalności Muzeum”. Pierwszy Synod Diecezji Zamojsko-Lubaczowskiej, Statut muzeum diecezjalnego, §12, s. 206. 
wołany urzędnik kościelny ma wydawać zarządzenia wewnętrzne w sprawie organizacji placówki muzealnej ${ }^{87}$. Wspomniane zarządzenia to przede wszystkim regulaminy wewnętrzne, pozostające w ścisłym związku ze statutem muzeum zatwierdzonym przez biskupa diecezjalnego ${ }^{88}$.

Trzeba dodać, że w sytuacjach, gdy statut muzeum diecezjalnego ma być sporządzony i uchwalony przez odpowiedzialnych za muzeum (autonomicznie uchwalony), to zostaje on włączony w porządek kanoniczny Kościoła przez przejrzenie, aprobatę lub zatwierdzenie ze strony właściwej władzy kościelnej ${ }^{89}$. W takich przypadkach pierwszorzędną rolę w powstaniu i uchwalenia statutu muzeum pełni jego dyrektor. Potwierdzają to przepisy, gdzie mówi się, że „Muzeum Diecezjalne posiada swój statut, zatwierdzony przez Ordynariusza diecezji”"90, czy „Muzeum posiada swój statut, zatwierdzony przez biskupa diecezjalnego" ${ }^{11}$. W kwestii sporządzenia i zatwierdzenia statutu muzeum charakterystyczny jest następujący passus: „Arcybiskup Metropolita Białostocki rozszerzył zakres działalności Muzeum Archidiecezjalnego w Białymstoku o działalność archiwalną i zmienił nazwę tej jednostki na Archiwum i Muzeum Archidiecezjalne w Białymstoku. Archiwum i Muzeum Archidiecezjalne w Białymstoku działać będzie w oparciu o przepisy prawa polskiego i kanonicznego oraz własny Statut. Arcybiskup Metropolita Białostocki zatwierdził i ogłosił poniższy Statut Archiwum i Muzeum Archidiecezjalnego"92. Prawodawcy mówią wyraźnie, że władza kościelna zatwierdza statut muzeum, co suponuje, że jest on sporządzony i uchwalony, a następnie przedstawiony przez odpowiedzialnych za muzeum do zatwierdzenia. Wskazuje to pośrednio, że dyrektor muzeum ma w powstaniu jego statutu pierwszoplanową rolę. Na udział dyrektora w powstawaniu statutu muzeum wskazują też następujące słowa okólnika La funzione pastorale dei musei ecclesiastici: ,gromadzenie i ochrona kościelnych dóbr kultury wymaga przestrzegania następujących zasad: zachowywania w tym zakresie norm i zaleceń Stolicy Swiętej, własnej Konferencji Episkopatu i biskupa diecezjalnego; zredagowania odpowiedniego statutu lub regulaminu" "93. Wolno sądzić, że przytoczone zarządzenie poleca odpowiedzialnym za muzeum sporządzenie jego statutu, skoro mają oni w tej kwestii zacho-

${ }^{87}$ Tamże, §10, 3, s. 206; por. Statut Muzeum Diecezji Kaliskiej, nr 17, s. 108.

88 „Muzeum Diecezjalne posiada swój (...) regulamin wewnętrzny nadany przez dyrektora Muzeum”. Statut Muzeum Diecezjalnego uchwalony przez Konferencje Episkopatu Polski, nr 23; por. Statut Muzeum Archidiecezjalnego w Przemyślu, art. 18, s. 300. „Zakres aktywności „działów” [muzeum] określa regulamin ustalony przez dyrektora". Statut Muzeum Diecezji Kaliskiej, nr 28, s. 110; por. Statut Muzeum Diecezjalnego w Łomży, §9.

${ }^{89}$ Por. kan. 94 §1; por. R. Sobański, Komentarz do kan. 94, w: Komentarz do Kodeksu Prawa Kanonicznego. T. 1. Ks. 1. Normy ogólne, red. J. Krukowski, Poznań 2003, s. 161. Jednak statut muzeum diecezjalnego może być wydany przez zewnętrzny w stosunku do muzeum podmiot władzy, czy to ustawodawczej, czy wykonawczej, a wtedy konkretny dyrektor, gdy muzeum, którym zarządza kieruje się tego typu statutem, nie bierze udziału w jego powstawaniu. Np. biskup diecezjalny mógłby nadać statut muzeum w swojej diecezji.

${ }^{90}$ Statut Muzeum Diecezjalnego uchwalony przez Konferencję Episkopatu Polski, nr 23

${ }^{91}$ Statut Muzeum Archidiecezjalnego w Przemyślu, art. 28, s. 300.

${ }^{92}$ Statut Archiwum i Muzeum Archidiecezjalnego w Białymstoku, s. 69.

${ }^{93}$ La funzione pastorale dei musei ecclesiastici, $\mathrm{nr}$ 3. 5. 
wywać przepisy władzy zewnętrznej w stosunku do muzeum: Stolicy Świętej, własnej Konferencji Episkopatu i biskupa diecezjalnego.

Jest rzeczą zrozumiałą, że dyrektor jest głównym odpowiedzialnym za majątek muzeum diecezjalnego, z czego wynikają określone obowiązki. Przede wszystkim winien on dbać, aby majątek muzeum nie uległ uszczupleniu. Stąd wraz z aktem nominacyjnym dyrektor powinien otrzymać wszelkie dane o aktualnym stanie rzeczy ruchomych i nieruchomych muzeum: specjalne wykazy, które poświadczają istnienie nieruchomości, szczegółowe inwentarze, informacje o zbiorach, dobrach i wyposażeniu wniesionym przez diecezję do muzeum. Dyrektor podejmując się swojej funkcji przyjmuje jednocześnie pełną i całkowitą odpowiedzialność zarówno co do opieki i ochrony różnych dóbr znajdujących się w placówce muzealnej, jak i co do funkcjonowania muzeum ${ }^{94}$. Dyrektor muzeum diecezjalnego ,prowadzi nadzór nad zbiorami i majątkiem muzeum” ", „do zakresu działania dyrektora należy w szczególności: (...) ogólny nadzór nad zasobami i majątkiem Archiwum i Muzeum" 96 . Dyrektor muzeum diecezjalnego winien się troszczyć o całość i nienaruszalność zbiorów muzealnych. Prawodawcy postanawiają, że ma on „obowiązek troszczyć się o całość i nienaruszalność muzealnych zbiorów"97, dyrektor ,troszczy się o bezpieczeństwo i integralność muzealiów”"98, „dyrektor Muzeum Odpowiada za całość zbiorów i ich stan"99.

Przejawem pieczy dyrektora o muzealia jest inwentaryzacja i opracowanie naukowe zasobu muzealnego ${ }^{100}$, strzeżenie inwentarzy i innej dokumentacji dotyczącą organizacji muzeum ${ }^{101}$, konserwacja , studiowanie, klasyfikowanie i zapewnienie utrzymania zbiorów ${ }^{102}$, powoływanie specjalistów w sprawach szczególnie ważnych dla zabytków i ich konserwacji ${ }^{103}$, troska o opracowanie i aktualizowanie dokumentacji zbiorów muzeum ${ }^{104}$, kierowanie sprawami naukowo-badawczymi

${ }^{94}$ Por. Statuto del Museo Diocesano di Arte Sacra Diocesi di San Benedetto del Tronto, Montalto, Ripatransone, art. 5.

95 Pierwszy Synod Diecezji Zamojsko-Lubaczowskiej, Statut muzeum diecezjalnego, §10, s. 206; por. Statut Muzeum Diecezji Kaliskiej, nr 17, s. 108.

${ }^{96}$ Statut Archiwum i Muzeum Archidiecezjalnego w Biatymstoku, §12, nr 2. 3, s. 73; por. Statut Muzeum Diecezjalnego w Łomży, §10.

${ }^{97}$ Statut Muzeum Diecezjalnego w Łomży, §19.

${ }^{98}$ Statut Muzeum Archidiecezjalnego w Przemyślu, art. 17, nr 3, s. 298.

${ }^{99}$ Statut Muzeum Diecezjalnego w Drohiczynie, nr 44, s. 46.

${ }^{100}$ Tamże; Statuto del Museo Diocesano di Arte Sacra Diocesi di San Benedetto del Tronto, Montalto, Ripatransone, art. 5.

${ }^{101}$ Tamże; Dyrektor muzeum winien dbać o stałe aktualizowanie inwentarza, a także o to, by jego kopia była przechowywana poza muzeum, co może mieć kapitalne znaczenie w przypadku zagubienia jakiegoś obiektu czy pożaru. Statuto del Museo Diocesano di Arte Sacra Diocesi di San Benedetto del Tronto, Montalto, Ripatransone, art. 7.

102 Statuto del Museo Diocesano di Arte Sacra Diocesi di San Benedetto del Tronto, Montalto, Ripatransone, art. 5.

${ }^{103}$ Statut Muzeum Diecezjalnego uchwalony przez Konferencję Episkopatu Polski, nr 17.

${ }^{104}$ Statut Muzeum Archidiecezjalnego w Przemyślu, art. 17, nr 4, s. 298. 
W muzeum ${ }^{105}$, dbanie o sprawność systemów zabezpieczeń przeciwpożarowych $\mathrm{i}$ antywłamaniowych ${ }^{106}$ oraz o stosowny monitoring ${ }^{107}$, zezwalanie lub odmawianie zezwolenia na wykonywanie zdjęć czy filmowanie na terenie ekspozycji ${ }^{108}$, urządzenie pomieszczeń dla zbiorów, przygotowanie sal wystawowych ${ }^{109}$.

Dyrektor muzeum ma starać się o powiększenie zasobu muzealiów poprzez zakupy „obiektów muzealnych, zwłaszcza tych, które mają znaczenie wzorcowe dla jakiegoś stylu, a mającym ważne znaczenie dla diecezji, którym grozi przejście do innego rejonu"110, a także poprzez darowizny i depozyty ${ }^{111}$.

Kolejnym obszarem działalności dyrektora jest udostępnianie muzealiów zwiedzającym. I tak dyrektor ma troszczyć się o odpowiednie eksponowanie i udostępnianie zwiedzającym zbiorów ${ }^{112}$, dbać o to, by zwiedzanie muzeum odbywało się w określonym porządku ${ }^{113}$, urządzać wystawy czasowe i stałe ${ }^{114}$, dbać o właściwy sposób prowadzenia wystaw i czas ich trwania ${ }^{115}$, pilnować, aby wystawy uwydatniały rozwój miejscowej sztuki religijnej i ilustrowały zagadnienia wiary $^{116}$, wyznaczać eksponaty na wystawy i do konserwacji ${ }^{117}$, decydować o udostępnianiu eksponatów znajdujących się w magazynach ${ }^{118}$.

Funkcja dyrektora zawiera w sobie obowiązek prowadzenia dokumentacji. Niektórzy prawodawcy domagają się wprost, aby dyrektor muzeum prowadził kancelarię $^{119}$, czy załatwiał korespondencję ${ }^{120}$.

Dyrektor muzeum diecezjalnego jest odpowiedzialny za świadczenie usług muzealnych, wśród których na pierwszym miejscu jest przewóz eksponatów muzealnych poza siedzibę muzeum w celu wypożyczenia, ekspozycji lub depozytu. Jest jednak w tej kwestii zobowiązany do przestrzegania obowiązującego prawa

105 Pierwszy Synod Diecezji Zamojsko-Lubaczowskiej, Statut muzeum diecezjalnego, §10, s. 206; Statut Muzeum Diecezjalnego w Drohiczynie, nr 44, s. 46.

${ }^{106}$ Statut Muzeum Diecezjalnego w Łomży, §19.

${ }^{107}$ Statuto del Museo Diocesano di Arte Sacra Diocesi di San Benedetto del Tronto, Montalto, Ripatransone, art. 9.

${ }^{108}$ Statut Muzeum Diecezjalnego w Drohiczynie, nr 5, s. 43.

${ }^{109}$ Statuto del Museo Diocesano di Arte Sacra Diocesi di San Benedetto del Tronto, Montalto, Ripatransone, art. 6.

${ }^{110}$ Statut Muzeum Diecezjalnego uchwalony przez Konferencję Episkopatu Polski, nr 17; Pierwszy Synod Diecezji Zamojsko-Lubaczowskiej, Statut muzeum diecezjalnego, §10, s. 206.

${ }^{111}$ Statut Muzeum Diecezjalnego w Drohiczynie, nr 44, s. 46.

${ }^{112}$ Statut Muzeum Archidiecezjalnego w Przemyślu, art. 17, nr 3, s. 298.

${ }^{113}$ Statuto del Museo Diocesano di Arte Sacra Diocesi di San Benedetto del Tronto, Montalto, Ripatransone, art. 6.

${ }^{114}$ Statut Muzeum Archidiecezjalnego w Przemyślu, art. 17, nr 5, s. 298.

${ }^{115}$ Statut Muzeum Diecezjalnego uchwalony przez Konferencję Episkopatu Polski, nr 13.

${ }^{116}$ Tamże; por. Statut Muzeum Diecezjalnego w Łomży, §6 g.

117 Pierwszy Synod Diecezji Zamojsko-Lubaczowskiej, Statut muzeum diecezjalnego, §10, s. 206; por. Statut Muzeum Diecezjalnego w Drohiczynie, nr 44, s. 46.

${ }_{118}$ Pierwszy Synod Diecezji Zamojsko-Lubaczowskiej, Statut muzeum diecezjalnego, §10, s. 206.

${ }^{119}$ Statut Muzeum Diecezjalnego w Drohiczynie, nr 44, s. 46.

${ }^{120}$ Statuto del Museo Diocesano di Arte Sacra Diocesi di San Benedetto del Tronto, Montalto, Ripatransone, art. 6. 
kanonicznego i państwowego tyczącego się ochrony obiektów religijnych, archeologicznych, artystycznych i historycznych oraz do uprzedniego uzyskania pisemnego upoważnienia biskupa diecezjalnego ${ }^{121}$.

Kolejnym zadaniem dyrektora muzeum diecezjalnego jest opracowanie projektu budżetu muzeum i przedłożenie go biskupowi diecezjalnemu lub ordynariuszowi miejsca do zatwierdzenia ${ }^{122}$. Wspomniany dyrektor ma także obowiązek składania sprawozdań finansowych muzeum ${ }^{123}$, a niekiedy musi w sprawach finansowych uzyskać zgodę ekonoma diecezjalnego ${ }^{124}$.

W przypadkach, gdy przy muzeum diecezjalnym istnieje i działa Rada Muzealna, która jest organem doradczym i opiniotwórczym Biskupa Diecezjalnego w sprawach Muzeum, to dyrektor muzeum jest członkiem wspomnianego gremium doradczego ${ }^{125}$. Niejednokrotnie prawodawcy postanawiają, że członków Rady Muzealnej powołuje biskup diecezjalny na wniosek dyrektora Muzeum ${ }^{126}$. Według niektórych przepisów prawa partykularnego Radę Muzeum zwołuje i przewodniczy jej dyrektor ${ }^{127}$.

Ważnym obowiązkiem dyrektora muzeum jest utrzymywanie kontaktów z muzeami kościelnymi i kurią diecezjalną. Np. Statut Muzeum Diecezjalnego uchwalony przez Konferencje Episkopatu Polski postanawia, że „,dyrektor muzeum powinien utrzymywać kontakty z muzeami kościelnymi innych diecezji”, ${ }^{28}$ Statut Muzeum Diecezji Kaliskiej, że „dyrektor muzeum, utrzymuje kontakty

${ }^{121}$ Por. tamże, art. 9.

${ }^{122}$ Statut Muzeum Diecezjalnego uchwalony przez Konferencję Episkopatu Polski, nr 17; „Dyrektor Muzeum na podstawie posiadanych funduszy opracowuje projekt budżetu Muzeum i raz w roku składa Biskupowi Łomżyńskiemu i Radzie Muzealnej sprawozdanie z jego realizacji”. Statut Muzeum Diecezjalnego w Łomży, §17; por. Statut Archiwum i Muzeum Archidiecezjalnego w Białymstoku, §13, nr 3, s. 73. „Budżet Muzeum Diecezjalnego w Drohiczynie i uposażenie jego pracowników ustala, na wniosek dyrektora lub kierownika administracyjnego, Diecezjalna Rada Gospodarcza, a zatwierdza Biskup Diecezjalny. Rozchód kontroluje Diecezjalna Komisja Rewizyjna”. Statut Muzeum Diecezjalnego w Drohiczynie, nr 10, s. 44-45.

123 Pierwszy Synod Diecezji Zamojsko-Lubaczowskiej, Statut muzeum diecezjalnego, §10, s. 206. „Oświadczenia w sprawach majątkowo-finansowych w imieniu Muzeum składa jego dyrektor i księgowy”. Statut Muzeum Diecezji Kaliskiej, nr 26, s. 109. „Do składania oświadczeń w zakresie praw i obowiązków majątkowych oraz podejmowania zobowiązań finansowych upoważniony jest wyłącznie dyrektor lub ustanowieni przez niego pełnomocnicy, w zakresie określonym w pełnomocnictwie". Statut Archiwum i Muzeum Archidiecezjalnego w Biatymstoku, §13, nr 3, s. 73.

124 „Finansami Archiwum i Muzeum zarządza dyrektor Archiwum i Muzeum Archidiecezjalnego. Jeśli czynność prawna przekracza wartość dwukrotnego średniego miesięcznego wynagrodzenia krajowego w gospodarce wymagana jest wcześniejsza zgoda ekonoma Archidiecezji Białostockiej”. Statut Archiwum i Muzeum Archidiecezjalnego w Białymstoku, §13, nr 2, s. 73.

${ }^{125}$ Statut Muzeum Diecezjalnego w Drohiczynie, nr 50, s. 47; Statut Muzeum Archidiecezjalnego w Przemyślu, art. 24-25, nr 5, s. 299; Statut Muzeum Diecezjalnego w Lomży, §13; Statut Muzeum Diecezji Kaliskiej, nr 20, s. 108.

${ }^{126}$ Statut Muzeum Diecezjalnego w Drohiczynie, nr 50, s. 47.

${ }^{127}$ Statut Muzeum Diecezji Kaliskiej, nr 21, s. 109; Statut Muzeum Diecezjalnego w Łomży, §14.

${ }^{128} \mathrm{Nr} 16$. 
z muzeami i ośrodkami zajmującymi się ochroną zabytków" ${ }^{129}$, a Statut Muzeum Diecezjalnego $w$ Łomży, że „dyrektor muzeum lub pracownicy przez niego upoważnieni, utrzymują kontakty z muzeami, ośrodkami zajmującymi się ochroną zabytków ${ }^{130}$. Natomiast Statut Archiwum i Muzeum Archidiecezjalne w Biatymstoku przypomina, że ,do zakresu działania dyrektora należy w szczególności: (...) współpraca z Kurią Metropolitalną Białostocką i jej wydziałami"131.

W celu zapewnienia stosownej formacji oraz profesjonalnego prowadzenia muzeum, jego dyrektor ma ,utrzymywać kontakty z muzeami kościelnymi innych diecezji i z Ośrodkiem Archiwów, Bibliotek i Muzeów Kościelnych przy Katolickim Uniwersytecie Lubelskim, zwłaszcza w sprawach organizacji zbiorów metody ich dokumentacji naukowej i opieki nad zabytkami na terenie diecezji"132, a także z ,ośrodkami zajmującymi się ochroną zabytków i wydziałami uczelni zajmujących się sztuką, zarówno kościelnymi jak i świeckimi. Kontakty te mają pomóc w aranżacji zbiorów, poznaniu nowoczesnych metod ich dokumentacji naukowej i konserwacji"133.

Dyrektor muzeum diecezjalnego pozostaje także w relacjach do pracowników muzeum. Rodzą się z tego liczne jego uprawnienia i obowiązki. Przede wszystkim dyrektor przyjmuje lub zwalnia - za zgodą Ordynariusza - pracowników muzealnych $^{134}$. Ustala on również zakres obowiązków pracowników muzealnych i kieruje ich zajęciami ${ }^{135}$. Prawodawcy w tej kwestii postanawiają: ,zakres obowiązków kustoszy, kierownika Archiwum Metrycznego oraz pozostałych pracowników Archiwum i Muzeum Archidiecezjalnego ustala dyrektor Archiwum i Muzeum"136, „dyrektorowi Archiwum i Muzeum Archidiecezjalnego podlegają i służą pomocą kustosz Archiwum Archidiecezjalnego, kustosz Muzeum Archidiecezjalnego i kierownik Archiwum Metrycznego. Mianuje ich i odwołuje Arcybiskup Metropolita Białostocki. Ich urząd jest kadencyjny. Kadencja trwa pięć lat i może być przedłużana na kolejne pięciolecia"137.

Prawodawcy kościelni mając na uwadze konieczność ochrony zabytkowych obiektów religijnych na terenie diecezji, zobowiązują dyrektora muzeum kościelnego do podjęcia określonych działań mających na celu zabezpieczenie i zacho-

${ }^{129} \mathrm{Nr} 18$, s. 108 .

$130 \S 11$.

$131 \S 12$, nr 2, 4, s. 73.

132 Statut Muzeum Diecezjalnego uchwalony przez Konferencje Episkopatu Polski, nr 15; por. Statut Muzeum Archidiecezjalnego w Przemyślu, art. 18, s. 298.

${ }^{133}$ Statut Muzeum Diecezjalnego w Łomży, §11.

${ }^{134}$ Statut Muzeum Diecezjalnego uchwalony przez Konferencję Episkopatu Polski, nr 17; Statut Muzeum Archidiecezjalnego w Przemyślu, art. 17, nr 2, s. 298; Pierwszy Synod Diecezji Zamojsko-Lubaczowskiej, Statut muzeum diecezjalnego, §11, s. 206; Statut Muzeum Diecezjalnego w Łomży, $\S 10$ b; Statut Muzeum Diecezji Kaliskiej, nr 17, s. 108.

${ }^{135}$ Statut Muzeum Diecezjalnego uchwalony przez Konferencję Episkopatu Polski, nr 17; Statut Muzeum Archidiecezjalnego w Przemyślu, art. 17, nr 2, s. 298; Pierwszy Synod Diecezji Zamojsko-Lubaczowskiej, Statut muzeum diecezjalnego, §11, s. 206; Statut Muzeum Diecezjalnego w Lomży, $\S 10$.

${ }^{136}$ Statut Archiwum i Muzeum Archidiecezjalnego w Białymstoku, §12, $\mathrm{nr}$ 4, s. 73.

${ }^{137}$ Tamże, §11, nr 3, s. 72. 
wanie wspomnianych dóbr kultury. I tak zwierzchnik muzeum diecezjalnego winien przede wszystkim prowadzić inwentaryzację zabytków, znajdujących się w kościołach, kaplicach i plebaniach na terenie diecezji, oraz gromadzić bibliografię dotyczącą muzeum i dokumentację fotograficzną ${ }^{138}$.

W przypadkach, gdy biskup diecezjalny podejmie decyzję o utworzeniu na terenie diecezji filii muzeum diecezjalnego, to głównym organizatorem tego typu placówek będzie dyrektor muzeum diecezjalnego, który jednocześnie będzie posiadał nad nimi zwierzchnictwo, a co za tym idzie będzie odpowiadał za ich funkcjonowanie $^{139}$.

\section{Podsumowanie}

Jest bardzo pożądane, aby każda diecezja posiadała własne muzeum, które ma spełniać w Kościele partykularnym zasadniczo dwa zadania: konserwacja diecezjalnego dziedzictwa artystycznego oraz jego dowartościowanie także na płaszczyźnie ściśle duszpasterskiej. U źródeł każdego muzeum diecezjalnego znajdują się praktyczne motywy ochrony, konserwacji i dowartościowania dziedzictwa artystycznego i kulturowego, będącego własnością Kościoła.

Muzeum diecezjalne choć ma swoja specyfikę, to jednak, jak każda instytucja tego typu potrzebuje określonego i wykwalifikowanego personelu. Wśród pracowników wspomnianego muzeum naczelne miejsce zajmuje jego dyrektor. Prawodawcy kościelni jednoznacznie uwypuklają potrzebę istnienia urzędu dyrektora muzeum diecezjalnego, eksplikują kwalifikacje i konieczność formacji zwierzchnika wspomnianego muzeum oraz szeroko formalizują zadania dyrektora muzeum diecezjalnego.

Słowa kluczowe: dyrektor muzeum diecezjalnego; muzeum diecezjalne; diecezja; biskup; statut; formacja

\section{BIBLIOGRAFIA}

\section{Źródła}

Arcybiskup Metropolita Białostocki, Statut Archiwum i Muzeum Archidiecezjalne w Białymstoku (4 maja 2012), „Wiadomości Kościelne Archidiecezji Białostockiej” 40 (2012), nr 2, s. 69-74.

Benedictus PP. XVI, Litterae Apostolicae motu proprio datae Antiqua ordinatione, „Quibus Supremi Tribunalis Signaturae Apostolicae lex propria promulgatur," (21 iunii 2008), „Acta Apostolicae Sedis”, 100 (2008) s. 513-538.

${ }^{138}$ Por. Statut Muzeum Diecezjalnego uchwalony przez Konferencje Episkopatu Polski, nr 17; Pierwszy Synod Diecezji Zamojsko-Lubaczowskiej, Statut muzeum diecezjalnego, §10, s. 206.

${ }^{139}$ Por. Statut Muzeum Diecezjalnego w Drohiczynie, nr 54, s. 47; Statut Muzeum Diecezjalnego $w$ Łomży, $\S 18$. 
Biskup Drohiczyński, Statut Muzeum Diecezjalnego w Drohiczynie (3 marca 2005), „Komunikaty Kurii Diecezjalnej w Drohiczynie n. Bugiem” 18 (2005), nr 2, s. 43-48.

Conferenza Episcopale Italiana, I beni culturali della Chiesa in Italia. Orientamenti (9 dicembre 1992), „Notiziario della Conferenza Episcopale Italiana” (1992), s. 309 336.

Conferenza Episcopale Italiana, I beni culturali della Chiesa in Italia. Orientamenti (9 dicembre 1992), „Notiziario della Conferenza Episcopale Italiana” (1992), s. 309 336.

Congregaticio pro Episcopis, Direttorio per il ministero pastorale dei vescovi (22 febbraio 2004), Città del Vaticano 2004, tekst polski: Kongregacja do spraw Biskupów, Dyrektorium o pasterskiej posłudze biskupów „Apostolorum Successores” (22 lutego 2004), Kielce 2005.

Ioannes Paulus P.P. II, Constitutio Apostolica Pastor Bonus, (28 iulii 1988), „Acta Apostolicae Sedis", 80 (1988) s. 841-912.

Pierwszy Synod Diecezji Rzeszowskiej, Statut Muzeum Diecezjalnego w Rzeszowie, Rzeszów 2004.

Pierwszy Synod Diecezji Zamojsko-Lubaczowskiej 1996-2001, Zamość 2001.

Pontificia Commissione per i Beni Culturali della Chiesa, Lettera circolare La funzione pastorale dei musei ecclesiastici (29 iunii 2001), [w:] Enchiridìon dei Beni Culturali della Chiesa. Documenti ufficiali della Pontificia Commissione per i Beni Culturali della Chiesa, Bologna 2002, s. 464-526.

Statut Muzeum Diecezjalnego uchwalony przez Konferencję Episkopatu Polski dnia (18 listopada 1976), „Currenda” 127 (1977), nr 5-8, s. 169-170.

Statut Muzeum Diecezjalnego w Łomży, www.kuria.lomza.pl (dostęp: 21.09.2015).

Statut Muzeum Diecezji Kaliskiej (3 lutego 2011), „Diecezja Kaliska. Pismo Kurii Diecezjalnej" 19 (2011), nr 1, s. 106-110.

Statuto del Museo Diocesano di Arte Sacra Diocesi di San Benedetto del Tronto, Montalto, Ripatransone, sistemimuseali.sns.it (dostęp: 23.08.2015).

Statuto del Museo Diocesano Tridentino (21 settembre 1981), (dostęp: 23.08.2015).

Statuty I Synodu Diecezji Pelplińskiej, Pelplin 2001.

Synod Archidiecezji Przemyskiej 1995-2000. Statuty i aneksy, Przemyśl 2000.

Synod Archidiecezji Wrocławskiej 1985-1991, Wrocław 1995.

Opracowania

Komentarz do Kodeksu Prawa Kanonicznego. T. 1. Ks. 1. Normy ogólne, red. J. Krukowski, Poznań 2003.

Komentarz do Kodeksu Prawa Kanonicznego. T. V. Ks. VII. Procesy, red. J. Krukowski, Poznań 2007.

Mały słownik terminów plastycznych, red. K. Zwolińska, Z. Malicki, Warszawa 1990.

Menis G., Muzea Kościoła, „Communio”, wersja polska 16 (1996), z. 6, s. 89-97.

Nowakowski B., Kompetentne i sprawnie działające trybunały kościelne. Rzeczywistość czy pobożne życzenie? Możliwości, perspektywy oraz konieczność zmian po słowach Benedykta XVI do Sygnatury Apostolskiej w 2011 r., „Prawo Kanoniczne”, 54 (2011) nr 3-4, s. 323-331.

Słownik wyrazów obcych. Wydanie nowe, red. E. Sobol, Warszawa 1991. 
THE DIOCESAN MUSEUM DIRECTOR'S OFFICE IN THE CANONIC VIEW

\section{Summary}

The following article is devoted to the office of the diocesan museum director in the canonic view. In the first part, the necessity of the diocesan museum director's job is presented. The second part depicts the qualifications and the formation of the diocesan museum director. The final part is devoted to the duties of the diocesan museum's leader.

Key words: director of the diocesan museum, diocesan museum, diocese, bishop, statute, formation 